\title{
Relationship between blood pressure and psychological features of experience and behaviour among teachers
}

\section{BACKGROUND}

Relationships between psychological features and psychophysical parameters, such as blood pressure, have a high relevance in research on coping with stress. We want to investigate the correlation between blood pressure and these psychological features.

\section{PARTICIPANTS AND PROCEDURE}

We investigated 79 teachers from high schools and secondary schools in and around Leipzig, Germany. Using the systolic blood pressure as an indicator, we formed three groups: hypotensive, normotensive, and hypertensive. We assessed several psychological health dependent variables and looked for differences between these groups ( $\chi^{2}$ test).

\section{RESULTS}

Hypotensive subjects experienced more stress and less planning and goal behaviour. Furthermore, they more of- ten used physical exercises in order to increase their social well-being. Hypertensive subjects, on the other hand, were driven by fear of loss of control and showed a higher sense of feeling threatened.

\section{CONCLUSIONS}

We found for each group different relationships that are highly relevant to health. This result shows how psychological features and physiological regulation mechanisms are linked.

\section{KEY WORDS}

blood pressure; well-being; psychological correlation; teachers; stress and coping

ORGANIZATION - 1: DPFA University of Applied Sciences Saxony, Germany · 2: University of Mainz, Germany .

3: University of Leipzig, Germany · 4: University of Evora, Portugal · 5: Islamic University of Indonesia, Indonesia AUthors' contributions - A: Study design - B: Data collection - C: Statistical analysis - D: Data interpretation .

E: Manuscript preparation · F: Literature search · G: Funds collection

CORRESPonding AUthor - Prof. Marcus Stueck, DPFA University of Applied Sciences Saxony, Mahlmannstraße 1-3, 04107 Leipzig, Germany, e-mail: marcus.stueck@dpfa-hs.de

to Cite this ARTICLE - Stueck, M., Rigotti, T., Roudini, J., Galindo, E., \& Utami, D. S. (2016). Relationship between blood pressure and psychological features of experience and behaviour among teachers. Health Psychology Report, 4(2),

128-136. doi: 10.5114/hpr.2016.56853

RECEIVED 29.10.2015 · REVIEWED 26.11.2015 · ACCEPTED 18.12.2015 · PUBLISHED 21.01.2016 


\section{BACKGROUND}

The grouping of teachers as a profession has received attention in the last decades as a result of multiple strains and the negative impacts of teaching on health (Gamsjaeger \& Sauer, 1995). In the perspective of new stress theory, which seeks a holistic concept of psychophysiological social health, this view is promising. An orientation towards prevention goes hand in hand with a multidimensional approach (cf. Schroeder, 2002; Schroeder \& Reschke, 1996b) by which an integrated relationship between psychological, biological and social components of the stress situation emerges. This study is a contribution towards a multifactorial view of strain and coping, focusing mainly on the reciprocal dynamic of psychological and somatic processes. We investigated the relationship between blood pressure and several psychological features in a group of teachers. We explain further about the results of the relationship between psychological coping and basic psycho-physiological regulation processes.

Blood pressure at any given point of time is the result of complex neuronal and hormonal forces as well as homeostatic interactions. The rhythmic activity of the heart consists of contraction (systole) and relaxation (diastole) of the heart muscle. With each heartbeat, the arterial blood pressure reaches its systolic value; between heartbeats, pressure reaches its diastolic value. Blood pressure has long been recognized in conventional medicine-oriented stress models as an important parameter of the experience of stress.

Mainly the central regulation unit, the hypothalamus, which receives impulses from the cortex and the limbic system, controls the complex regulation of blood pressure. The limbic system is related to the origin of emotions and explains the influence of psychological condition related to emotional state to the effect of heart-circulation system. Blood pressure correlates with various emotional states as well as with several individual stress-coping styles (Hecht et al., 2001):

- emotional (e.g., anger in/anger out, anxiety, depression),

- cognitive (e.g., irrational beliefs),

- behavioural (e.g., coping styles, health behaviour),

- personality (e.g., mental health, sense of coherence).

This suggests that health psychology should seek a multidimensional approach by determining the relationship between blood pressure and relevant health variables. Current literature lacks data concerning blood pressure as a physiological parameter and how it is connected to strain for teachers. Most of the studies focus only on high blood pressure. Hlavkova, Blazkova, Prochazka, and Kozena (1998) for example reported that teachers with high systolic blood pressure were characterized by higher hostility, irritability, inability to relax, and by higher subjectively felt job stress. In a Dutch study on 262 teachers, those with treated hypertension reported more symptoms than untreated hypertensive and normotensive subjects (Nyklicek, Vingerhoets, Van Heck, \& Kamphius, 1997).

However, the few studies done using a broader classification of blood pressure show interesting findings. Schalling and Svensson (1984) demonstrated a significant correlation between low blood pressure (hypotension) and high levels of aggression and animosity in a normal population. Furthermore, Wittmann (1989) reported a moderate negative correlation $(r=.66)$ between blood pressure and depression scores, thus inferring a relationship between low blood pressure and depressive malaise. Also, Oberleiter (1986) showed a connection between low blood pressure and depressive mood, a tendency towards avoidance and withdrawal in stressful situations, and psycho-vegetative discomfort since the elementary school year. In a sample of 98 clinically healthy teachers, Scheuch (1982) found sleeping problems (49\%), a lowering of the heart rate, and an increase of the systolic blood pressure and the pulse pressure within one school year (September to July). The authors used scientific staff as a control group. Additionally, the authors found correlations between sleeping problems and diastolic blood pressure $(r=.30)$, between sleeping problems and peripheral vascular resistance $(r=.50)$, and between sleeping problems and blood volume and tone of the brain vessels of both hemispheres $(r=.18)$.

In the present study, we aim to answer the question: what may be the psychological differences among participants with low blood pressure (hypotension), high blood pressure (hypertension), and normal blood pressure (normotension)?

\section{PARTICIPANTS AND PROCEDURE}

\section{PARTICIPANTS}

We investigated 79 teachers in schools in Leipzig, Germany and chose the participants randomly. The bulk of the subjects (58.40\%) were high school teachers, approximately a third (36.40\%) taught in secondary schools, and a small proportion $(5.20 \%)$ taught in elementary schools. The average age of all participants was 43 years. Females were over-represented, as they comprised $80.00 \%$ of the total sample. The average age of female teachers was 41.80 years, whereas male teachers had an average age of 46.50 years. The majority of all participants taught two or three subjects. We designed the study as a $3 \times 1$ research model. Three experimental groups (hypotension, hypertension, and normotension) varied systematically for one assessment.
Blood pressure and psychology 


\section{MATERIALS AND PROCEDURE}

In order to keep the experimenter effect stable, we involved only one experimenter and always measured the psychophysiological parameters in the morning. To assess the large pool of stress-relevant dependent variables with an assumed relationship to the systolic blood pressure, we worked mainly with standardised questionnaires from the fields of Clinical Psychology, Personality Psychology, and Work and Organisational Psychology (Sonntag, 2001, see Table 1). Using these instruments, we were able to

Table 1

Dependent variables and underlying instruments

Marcus Stueck, Thomas Rigotti, Juliet Roudini, Edgar Galindo, Dian S. Utami

\begin{tabular}{lc}
\hline $\begin{array}{l}\text { Dependent } \\
\text { variables }\end{array}$ & Instruments \\
\hline $\begin{array}{l}\text { Mental health } \\
\text { control of behaviour }\end{array}$ & $\begin{array}{c}\text { Trierer Personality In- } \\
\text { ventory (TPF) } \\
\text { (Becker, 1989) }\end{array}$ \\
$\begin{array}{l}\text { Work-related } \\
\text { patterns of } \\
\text { behaviour and } \\
\text { experience }\end{array}$ & $\begin{array}{c}\text { Work related patterns of } \\
\text { behaviour and experi- } \\
\text { ence (AVEM) } \\
\text { Stress-relevant } \\
\text { coping }\end{array}$ \\
$\begin{array}{c}\text { Questionnaire to analyse } \\
\text { stress-relevant coping } \\
\text { Personal stress } \\
\text { scopes }\end{array}$ & styles (FABA) \\
\end{tabular}

Regulation of emotions

Complaints

Competence and Control belief

Stress-medical history questionnaire
State-Trait-Anxiety Inventory (STAI)

State-Trait-Anger Expression Inventory (STAXI)

Emotionality Inventory

Complaints-questionnaire (BFB)

Questionnaire for Competence and Control
(Becker, 1989)

(Schaarschmidt \& Fischer, 1996)

(Richter, Rudolf, \& Schmidt, 1996)

(Schröder \& Reschke, Seven scales (i.e., loss of control 1996a) and sense, punctual stress subject belief (FKK)

Questionnaire for self-efficacy

Sense of coherence Sense of coherence questionnaire (SOC-13)

(Hecht \& Balzer, 1996)

(Laux, Glanzmann, Schaffner, \& Spielberger, 1981)

(Schwenkmezger, Hodapp,

\& Spielberger, 1992)

(Ullrich De Muynck \& Ullrich, 1977)

(Höck \& Hess, 1981)

(Krampen, 1991)

(Jerusalem, 1990)

(Schuhmacher, Wilz, Gunzelmann, \& Brähler, 2000)

Stress-coping styles Stress-Coping Question- (Reschke \& Schröder naire 1994) and social support)

Four scales (inability to relax, ambitions to plan, impatience, dominance)

Identification of work-related mental risk behaviour (11 scales)

Habitual personality features on 9 scales (i.e., mental health, control of behaviour)

Five scales (i.e., experienced stress, stress-somatic symptoms)

Two scales (Trait-anxiety, State-worries)

Four scales (i.e., anger-in, anger-out, anger-control)

Seven emotional reaction classes (i.e., anxiousness, inhibited state, sense of being lost)

Two scales (neuroses relevant physical, and mental complaints)

Four primary scales: general self-concept of own abilities, internality, social externality, fatalistic externality

Action orientation

Assessment of the personal trait sense of coherence as a coping style for stress

Assessment of stress and coping styles (i.e., sense of menace, optimism, active emotional coping) 
measure several stress and health relevant features of the participants. Blood pressure was measured with a machine used commonly for this practice.

In order to analyse the dependent variables, we used test-specific stencils and special software to generate the AVEM test (work-related behaviour and experience pattern). Using the results of the blood pressure measurements, participants were divided into three groups (hypotensive, hypertensive, and normotensive). We used the systolic blood pressure as an indicator. Characteristics of the three resulting groups are shown in Table 2. The participants across these three groups are homogeneous in terms of age. The diagnosis of hypertension was made referring to the criteria of the World Health Organisation (1999). As the WHO does not define criteria for hypotension, we used instead the classification of Huep (1973). Persons with neither high nor low systolic blood pressure were categorised as normotensive.

In order to show the differences between hypo-, normo-, and hypertensive for the interval scaled values from the questionnaires, we used a non-parametric test (Mann-Whitney $U$ test). For analysis of nominal data (the variables "stress cognitions" and "complaints"), we analysed the differences in the distribution with the $\chi^{2}$ test. We present those results that are significant in level 0.05 or 0.10 .

\section{RESULTS}

\section{PSYCHOLOGICAL FEATURES}

IN THE COMPARISON OF HYPOTENSIVE AND NORMOTENSIVE GROUPS (ORDINAL DATA)

Table 3 shows results of research finding differences in average scores between hypo- and normotensive groups for several psychological parameters.

The hypotensive group, compared to the normotensive group, shows significant differences in some dimensions. The hypotensive group shows less severe excessive planning and goal-seeking behaviour, connected with a low need of control $(p=.030)$. They can control anger less effectively $(p=.040)$ and more frequently state that they know the health effects of physical exercise $(p=.020)$. This group reported using phys- ical exercises more often in social situations as a way to increase their social well-being $(p=.050)$, although they are less satisfied with the extent of their activities $(p=.020)$ and with their present well-being $(p=.040)$.

Significant trends were found when comparing hypoand normotensive groups in some aspects. The hypotensive group shows lower faith in dependency on external circumstances or on other people (externality, $p=.090$; social externality, $p=.090$ ) rather than the normotensive group. They show a lower level of work engagement $(p=.080)$ and a lower level of striving for perfection $(p=.080)$, although they also sleep less regularly $(p=.080)$.

\section{PSYCHOLOGICAL FEATURES}

IN THE COMPARISON OF HYPERTENSIVE AND NORMOTENSIVE GROUPS (ORDINAL DATA)

Table 4 shows the results for average score differences between hypertensive and normotensive groups for several psychological parameters. We show only those results which are significant at a $5.00 \%$ level or which indicate a significant trend at a $10.00 \%$ level.

Compared to the normotensive group, the hypertensive group shows significant differences, such as feel stronger emotions to be left $(p=.010)$, and they report their actual state as less spontaneous $(p<.001)$. They also show a stronger sense of menace $(p=.050)$.

In the other findings, we found a significant tendency of this group towards the following features: a higher inability to relax $(p=.060)$, use of physical activity more often in social situations in order to increase their social well-being $(p=.080)$, and higher scores for impaired general well-being $(p=.050)$ along with higher anxiety $(p=.100)$.

\section{DIFFERENCES BETWEEN THE THREE BLOOD PRESSURE GROUPS IN SELECTED DIMENSIONS OF EXPERIENCE AND BEHAVIOUR \\ (NOMINAL DATA)}

\section{Blood pressure and stress cognition}

We used the $\chi^{2}$ test to investigate differences in the distribution of observed and expected frequencies

Table 2

Classification of blood pressure values referring to WHO-ISH (1999) and Huep (1973) and frequencies of blood pressure types among participants

\begin{tabular}{lccc}
\hline & Normotensive & Hypertensive & Hypotensive \\
\hline Systolic blood pressure & $110-139 \mathrm{mmHg}$ & $>139 \mathrm{mmHg}$ & $<110 \mathrm{mmHg}$ \\
Diastolic blood pressure & $70-89 \mathrm{mmHg}$ & $>89 \mathrm{mmHg}$ & $<70 \mathrm{mmHg}$ \\
$n$ & 40 & 22 & 17 \\
$\%$ & 50.63 & 27.85 & 21.52 \\
\hline
\end{tabular}


Table 3

Marcus Stueck, Thomas Rigotti, Juliet Roudini, Edgar Galindo, Dian S. Utami

Significant average score comparisons between hypotensiveand normotensive groups for psychological parameters

\begin{tabular}{|c|c|c|c|c|c|}
\hline Psychological parameters & & $\begin{array}{l}\text { Hypotensive } \\
\quad n=17\end{array}$ & $\begin{array}{l}\text { Normotensive } \\
\quad n=40\end{array}$ & $\begin{array}{c}\text { Significance } \\
p\end{array}$ & $\begin{array}{c}\text { Effect size } \\
\quad d\end{array}$ \\
\hline \multirow{2}{*}{$\begin{array}{l}\text { Competence and control belief / } \\
\text { Social externality }\end{array}$} & $M$ & 46.63 & 51.65 & \multirow{2}{*}{.090} & \multirow{2}{*}{0.52} \\
\hline & $S D$ & 9.25 & 10.16 & & \\
\hline \multirow{2}{*}{$\begin{array}{l}\text { Competence and control belief / } \\
\text { Externality }\end{array}$} & $M$ & 43.25 & 48.15 & \multirow{2}{*}{.090} & \multirow{2}{*}{0.54} \\
\hline & $S D$ & 8.09 & 10.04 & & \\
\hline \multirow{2}{*}{$\begin{array}{l}\text { Stress relevant } \\
\text { coping / Excessive ambition } \\
\text { for planning }\end{array}$} & $M$ & 17.56 & 19.35 & \multirow[b]{2}{*}{.030 } & \multirow[b]{2}{*}{0.67} \\
\hline & $S D$ & 2.87 & 2.44 & & \\
\hline \multirow{2}{*}{$\begin{array}{l}\text { Work related pattern of } \\
\text { behaviour and } \\
\text { Experience (AVEM) / Work } \\
\text { engagement }\end{array}$} & $M$ & 238.56 & 249.02 & \multirow[b]{2}{*}{.080} & \multirow[b]{2}{*}{0.55} \\
\hline & $S D$ & 16.98 & 20.61 & & \\
\hline \multirow{2}{*}{$\begin{array}{l}\text { Work related pattern of } \\
\text { behaviour and } \\
\text { Experience (AVEM) / Strive for } \\
\text { perfection }\end{array}$} & $M$ & 46.69 & 51.59 & \multirow[b]{2}{*}{.080} & \multirow[b]{2}{*}{0.59} \\
\hline & $S D$ & 8.18 & 8.46 & & \\
\hline \multirow{2}{*}{$\begin{array}{l}\text { State-Trait-Anger Expression } \\
\text { Inventory (STAXI) / Anger } \\
\text { control (Stanine values) }\end{array}$} & $M$ & 4.82 & 5.56 & \multirow[b]{2}{*}{.040} & \multirow[b]{2}{*}{0.50} \\
\hline & $S D$ & 1.24 & 1.70 & & \\
\hline \multirow{2}{*}{$\begin{array}{l}\text { Health behaviour / Physical } \\
\text { exercise as layman aetiology }\end{array}$} & $M$ & 61.50 & 52.82 & \multirow{2}{*}{.020} & \multirow{2}{*}{1.00} \\
\hline & $S D$ & 6.89 & 10.12 & & \\
\hline \multirow{2}{*}{$\begin{array}{l}\text { Health behaviour / Social well- } \\
\text { being through physical exercise }\end{array}$} & $M$ & 54.25 & 44.00 & \multirow{2}{*}{. 050.} & \multirow{2}{*}{1.05} \\
\hline & $S D$ & 8.21 & 11.08 & & \\
\hline \multirow{2}{*}{$\begin{array}{l}\text { Health behaviour / Satisfaction } \\
\text { with own physical exercise }\end{array}$} & $M$ & 46.20 & 51.46 & \multirow{2}{*}{.020} & \multirow{2}{*}{0.59} \\
\hline & $S D$ & 9.83 & 7.97 & & \\
\hline \multirow{2}{*}{$\begin{array}{l}\text { Health behaviour / Regularity of } \\
\text { sleep }\end{array}$} & $M$ & 45.50 & 50.67 & \multirow{2}{*}{. 020} & \multirow{2}{*}{0.55} \\
\hline & $S D$ & 9.74 & 9.13 & & \\
\hline \multirow{2}{*}{$\begin{array}{l}\text { Health behaviour / Current well- } \\
\text { being }\end{array}$} & $M$ & 45.81 & 49.80 & \multirow{2}{*}{.040} & \multirow{2}{*}{0.52} \\
\hline & $S D$ & 7.57 & 7.68 & & \\
\hline
\end{tabular}

between the three blood pressure groups concerning stress cognitions we asked about. Hypertensive subjects most often responded yes to the following items of stress cognition (internal incentives): "I cannot rely on others" $(38.10 \%, p<.001)$, "I must not lose control" (66.70\%, $p=.020)$, and "I have not learned to pay attention to the warning signals of my body" $(47.60 \%$, $p=.030$, see Figure 1 ).

\section{Blood pressure and complaints}

Concerning the blood pressure and the reported complaints (BFB, Hoeck \& Hess, 1981) of participants, we found some relationships (see Figure 2). First, hypotensive subjects, compared to normotensive and hy- pertensive subjects, suffer more often from obstipation, which indicates high parasympathetic activation (43.80\%, $p=.050)$. Second, hypotensive subjects less often experience body parts falling asleep $(12.50 \%$, $p=.030)$. Third, hypotensive subjects rarely note sensitivity to odour $(4.80 \%, p=.020)$.

\section{DISCUSSION}

In the present study, we found tendentious, but also very strong relationships between blood pressure and psychological features in a sample of teachers. This shows how psychological features and physiological regulation mechanisms are linked. The differences 
Table 4

Significant average score comparisons between hypertensive and normotensive group for psychological parameters

\begin{tabular}{|c|c|c|c|c|c|}
\hline Psychological parameters & & $\begin{array}{c}\text { Hypertensive } \\
n=22\end{array}$ & $\begin{array}{c}\text { Normotensive } \\
\quad n=40\end{array}$ & $\begin{array}{c}\text { Significance } \\
p\end{array}$ & $\begin{array}{c}\text { Effect size } \\
\quad d\end{array}$ \\
\hline \multirow{2}{*}{$\begin{array}{l}\text { Stress relevant } \\
\text { coping / Incompetence to relax }\end{array}$} & $M$ & 17.00 & 14.83 & \multirow{2}{*}{.060} & \multirow{2}{*}{0.52} \\
\hline & $S D$ & 3.92 & 4.37 & & \\
\hline \multirow{2}{*}{$\begin{array}{l}\text { Health behaviour / Social } \\
\text { well-being through physical } \\
\text { exercise }\end{array}$} & $M$ & 52.36 & 44.00 & \multirow[b]{2}{*}{.080} & \multirow[b]{2}{*}{0.77} \\
\hline & $S D$ & 10.65 & 11.08 & & \\
\hline \multirow[t]{2}{*}{ Somatic symptoms from stress } & $M$ & 19.09 & 15.17 & \multirow{2}{*}{.090} & \multirow{2}{*}{0.49} \\
\hline & $S D$ & 8.77 & 7.33 & & \\
\hline \multirow[t]{2}{*}{ General experience of stress } & $M$ & 44.77 & 38.74 & \multirow{2}{*}{.080} & \multirow{2}{*}{0.45} \\
\hline & $S D$ & 13.88 & 12.86 & & \\
\hline \multirow{2}{*}{$\begin{array}{l}\text { Emotionality Inventory / } \\
\text { Anxiousness }\end{array}$} & $M$ & 61.63 & 54.08 & \multirow{2}{*}{.100} & \multirow{2}{*}{0.59} \\
\hline & $S D$ & 11.19 & 14.29 & & \\
\hline \multirow{2}{*}{$\begin{array}{l}\text { Emotionality Inventory / } \\
\text { Inhibited state }\end{array}$} & $M$ & 31.73 & 25.76 & \multirow{2}{*}{.000} & \multirow{2}{*}{1.13} \\
\hline & $S D$ & 5.16 & 5.36 & & \\
\hline \multirow{2}{*}{$\begin{array}{l}\text { Emotionality Inventory / } \\
\text { Sense of being lost }\end{array}$} & $M$ & 28.00 & 23.44 & \multirow{2}{*}{.010} & \multirow{2}{*}{0.97} \\
\hline & $S D$ & 3.55 & 5.63 & & \\
\hline \multirow{2}{*}{$\begin{array}{l}\text { Emotionality Inventory / } \\
\text { Impaired general well-being }\end{array}$} & $M$ & 63.27 & 53.25 & \multirow{2}{*}{.050} & \multirow{2}{*}{0.80} \\
\hline & $S D$ & 12.94 & 12.03 & & \\
\hline \multirow{2}{*}{$\begin{array}{l}\text { Stress-Coping / } \\
\text { Sense of menace }\end{array}$} & $M$ & 6.95 & 5.80 & \multirow{2}{*}{.050} & \multirow{2}{*}{0.55} \\
\hline & $S D$ & 2.06 & 2.09 & & \\
\hline
\end{tabular}

I have not learned to give attention to the warning signals of my body $(p=.030)$

I must not loose control $(p=.020)$
I am quilty for everything $(p=.090)$
I fight shy of trouble and problems
$(p=.090)$

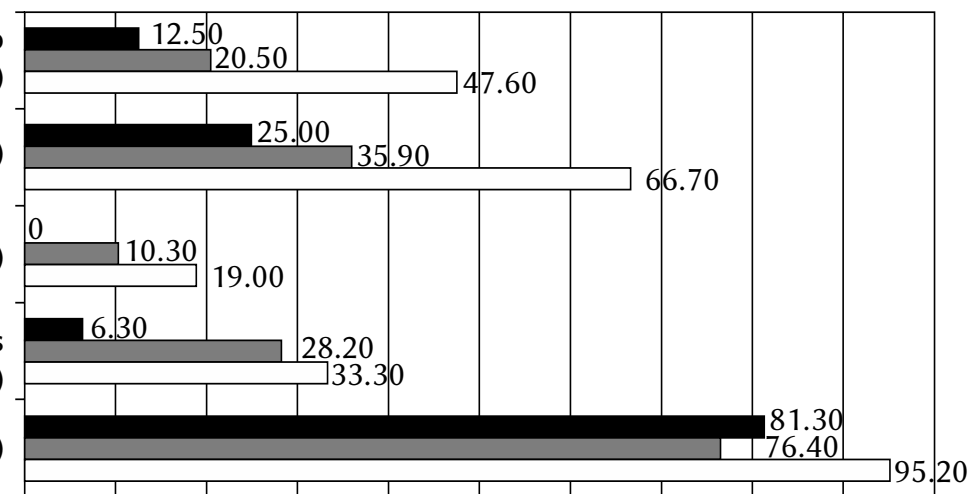

I can not rely on others $(p<.001)$

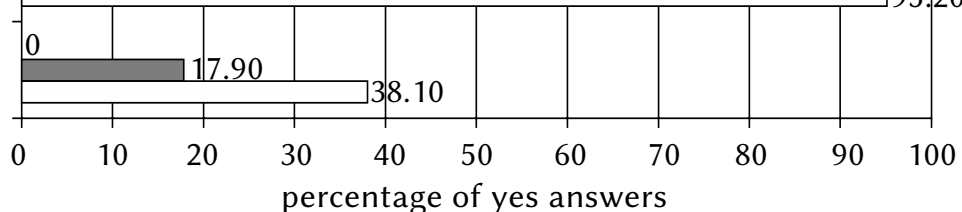

- hypertensives $\square$ normotensives $\square$ hypotensives

Figure 1. Differences in the percentage of yes answers to stress cognitions.

between groups with different blood pressures are significant because of the reciprocal conditionality of blood pressure and psychological features. Following the results of this study, hypotensive teachers show a reduced work engagement and a lower planning behaviour. They exercise more often, but are less satisfied with the extent of their physical exercises. Furthermore, the hypotensive group shows a stronger
Blood pressure and psychology 
Marcus Stueck, Thomas Rigotti, Juliet Roudini, Edgar Galindo, Dian S. Utami

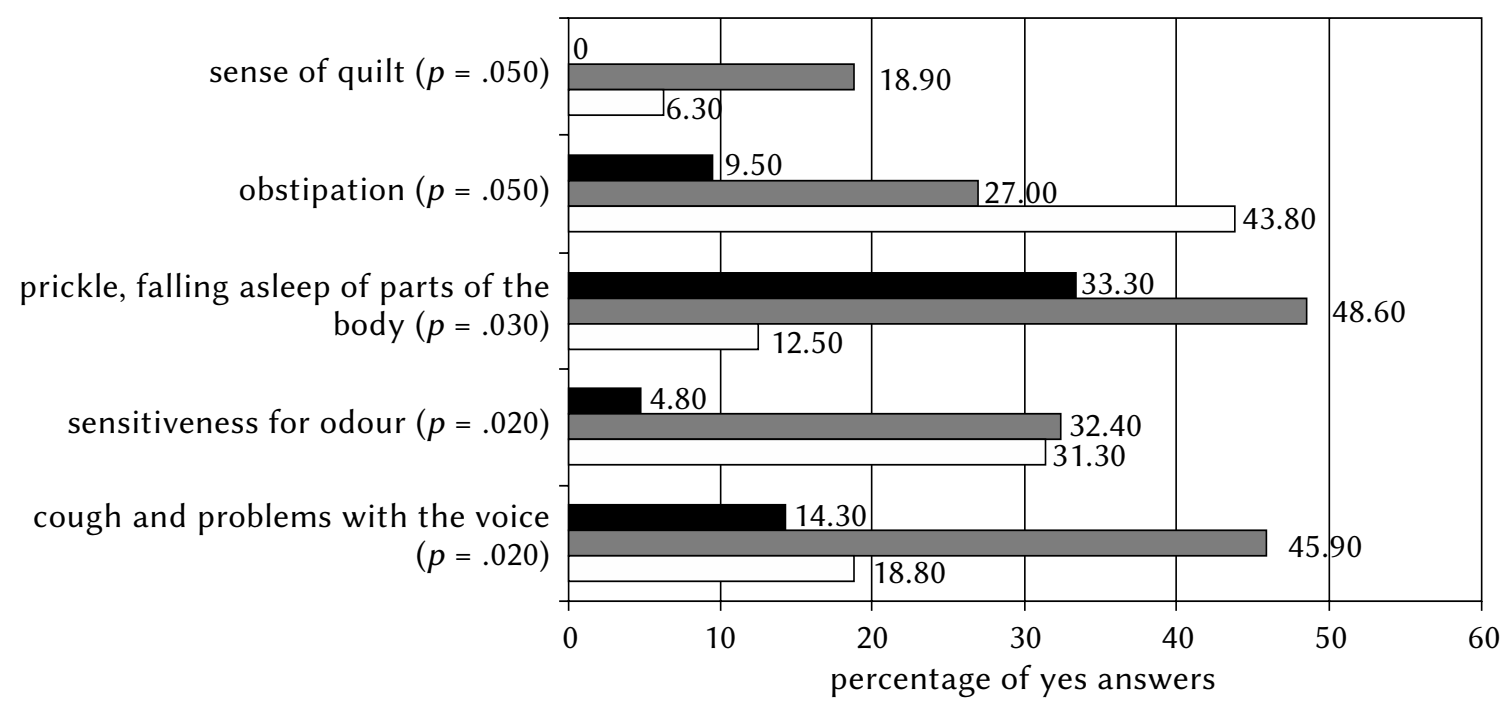

- hypertensives $\square$ normotensives $\square$ hypotensives

Figure 2. Significant differences in the frequency of complaints for the three groups with different blood pressure.

experience of discomfort. A previous study showed that the association between low blood pressure and depressed mood was significant when moderated with situational stress in persons (Davydov, Stewart, Ritchie, \& Chaudieu, 2012). Contrary to other studies (Oberleiter, 1986; Wittmann, 1989), which demonstrated that low blood pressure was associated with depressive symptoms, we found a significant relationship between blood pressure and health behaviour (i.e., physical exercise, social well-being, satisfaction with own physical exercise, regularity of sleep, and current well-being). Rather, teachers with lower blood pressure in this study showed a higher experience of sense in life than teachers with high blood pressure.

Hypertensive subjects showed a stronger sense of menace than hypotensive subjects and describe more frequent stress cognitions as well as a higher general stress experience as compared to the other groups.

A relationship between hypotension and stronger anger emotions, as well as the suppression of anger, was not found. Hypertensive subjects show a higher sense of being lost and show an increased stress cognition for "I cannot rely on others".

High blood pressure is also called "the silent killer", since in the long term the risk of heart diseases and strokes is much higher for hypertensive subjects. Nevertheless, regarding the individually reported well-being, hypertensive subjects constantly report fewer somatic complaints and overall seem more satisfied with their health, as compared to hypotensive subjects. From a medical point of view, hypotension has not received much attention, as it is perceived as not having an impact on health deterioration. Although no relationship between depressive symptoms and low blood pressure was found in this study, there are reasons to expect risks for hypotensive subjects regarding mental health rather than somatic problems.

\section{CONCLUSIONS}

The reciprocal interaction of physiological and psychological parameters on the one hand and a cross-sectional study on the other make it impossible to draw conclusions about causality. We suggest for future research that this finding should be observed with more subjects. This also includes the measurement of parasympathetic activation, which would be useful to observe the impact of obstipation among hypotension, normotension, and hypertension related to psychological parameters. Thus, for instance, it is considered to use extra electrocardiograph laboratory testing.

Teachers are known to experience high strain, mostly due to role ambiguity. Burnout, early retirement and psychosomatic complaints are just a few indicators that have proven frequent in the teaching profession. Knowledge about blood pressure and its effects on mental and physical health could be included in health programs for teachers. In addition to training teachers with coping strategies, behaviour geared towards better health might be an important factor in improving the situations of teachers.

\section{References}

Becker, P. (1989). Der Trierer Persoenlichkeitsfragebogen (TPF) [The "Trierer" personality inventory]. Goettingen: Hogrefe. 
Davydov, D. M., Stewart, R., Ritchie, K., \& Chaudieu, I. (2012). Depressed mood and blood pressure: The moderating effect of situation-specific arousal levels. International Journal of Psychophysiology, 85, 212-223.

Gamsjaeger, E., \& Sauer, J. (1995). Burnout bei Lehrern: Eine empirische Untersuchung bei Hauptschullehrern in Oesterreich [Burnout of teachers: An empirical study with Austrian secondary school teachers]. Psychologie in Erziehung und Unterricht, 43, 40-56.

Hecht, K., Andler, S., Breinl, S., Voigt-Spychala, C., Stueck, M., \& Lander, H. J. (2001). Objektive Kontrolle der Selbstentspannungsfaehigkeit mittels Zeitreihenmessungen des Blutdrucks und der Elektrodermalen Aktivitaet (EDA) [Objective control of self-relaxation ability by time series measurements of blood pressure and the electrodermal activity]. In K. Hecht, H. P. Scherf, \& O. Koenig (eds.), Emotioneller Stress durch Ueberforderung und Unterforderung [Emotional Stress] (pp. 253-272). Berlin.

Hecht, K., \& Balzer, H. U. (1996). Klassifizierung des psychophysiologischen Regulationsverhaltens [Classification of the psychophysiological regulation behaviour] (Nutzerhandbuch). Berlin: Instituts für Stressforschung Berlin.

Hlavkova, J., Blazkova, V., Prochazka, B., \& Kozena, L. (1998). Cardiovascular reactions to job stress in teachers. Homeostasis in Health \& Disease, 39, 32-37.

Hoeck, K., \& Hess, H. (1981). Beschwerdenfragebogen $(B F B)$ [Complaint questionnaire]. Berlin: VEB Deutscher Verlag der Wissenschaften.

Huep, W. W. (1973). Klinik der Hypotonie. In D. Gross (ed.), Hypo- und Hypertonie [Hypo, and Hypertony] (pp. 132-144). Stuttgart: Hippokrates Verlag.

Jerusalem, M. (1990). Persoenliche Ressourcen, Vulnerabilität und Streßerleben [Personel Resources, vulnerability and expirienced stress]. Goettingen: Hogrefe.

Krampen, G. (1991). Fragebogen zu Kontroll- und Kompetenzerwartungen [Questionnaire for control and competenc expectancy]. Goettingen: Hogrefe.

Laux, L., Glanzmann, P., Schaffner, P., \& Spielberger, C. D. (1981). State-Trait-Angst-Inventar (STAI) [State-Trait-Anxiety inventory]. Weihnheim: Beltz.

Nyklicek, I., Vingerhoets, A. J. J. M., Van Heck, G. L., \& Kamphius, P. L. (1997). Blood pressure, self-reported symptoms and job related problems in schoolteachers. Journal of Psychosomatic Research, 42, 287-296.

Oberleiter, F. (1986). Biografisch-psychologische Hintergruende der essentiellen Hypotonie. Studien zu einem anthropologisch-ganzheitlichen Menschenund Krankheitsverständnis [Biographic-psycho- logical backgrounds of essentiel Hypotony. Studies for a anthropologic-holistic man and sickness approach]. Unpublished Dissertation. Universität Salzburg, Salzburg.

Reschke, K., \& Schroeder, H. (1994). Szenenwechsel im Alltag. Identitäts- und Zukunftsorientierung für Arbeitslose [Change of scenes in daily life. Identity and orientation for the future for unemployed]. Deutsches Institut für Erwachsenenbildung (DIE).

Richter, P., Rudolf, M., \& Schmidt, C. F. (1996). Fragebogen zur Analyse belastungsrelevanter Anforderungsbewältigung (FABA) [Questionnaire to analyse strain relevant coping]. Frankfurt: Swets.

Schaarschmidt, U., \& Fischer, A. (1996). Arbeitsbezogenes Verhaltens- und Erlebensmuster (AVEM) [Work related behavioural and experience pattern]. Frankfurt: Swets.

Schalling, D., \& Svensson, J. (1984). Blood pressure and personality. Personality and Individual Differences, 5, 41-51.

Scheuch, K. (1982). Lehrertaetigkeit, Lehrerpersoenlichkeit, Lehrergesundheit [Teaching, teacher personality, teacher health] (University Reports No. 6). Rostock: Wilhelm-Pieck-Universitaet Rostock; Sektion Paedagogik und Psychologie.

Schroeder, H. (2002). Krankheitspraevention und Gesundheitsfoerderung [Sickness prevention and health promotion]. In E. Braehler \& B. Strauß (eds.), Handlungsfelder in der Psychosozialen Medizin [Action field in the Psychosocial Medicine] (pp. 359-376). Goettingen: Hogrefe.

Schroeder, H., \& Reschke, K. (1996a). Optimistisch den Stress meistern. Ergebnisse der Evaluation eines neuen Stressbewaeltigungsprogramms [Optimistic coping of stress. Results of an evaluation of a new stress coping programm]. Leipzig: Institut für Angewandte Psychologie.

Schroeder, H. \& Reschke, K. (eds.). (1996b). Psychosoziale Praevention und Gesundheitsfoerderung [Psychosocial Prevention and health promotion]. Regensburg: S. Roderer.

Schuhmacher, J., Wilz, G., Gunzelmann, T., \& Braehler, E. (2000). Die Sense of Coherence Scale von Antonovsky - Teststatistische Ueberpruefung in einer repraesentativen Bevoelkerungsstichprobe und Konstruktion einer Kurzskala [The Sense of Coherence Scale of Antonovsky - test statistical revise with a representative sample and construction of a short scale]. Diagnostica, 46, 208-213.

Schwenkmezger, P., Hodapp, V., \& Spielberger, C. D. (1992). State-Trait-Aergerausdrucks-Inventar(STAXI) [State-Trait-Anger Inventory]. Goettingen: Huber.

Sonntag, A. (2001). Psychologische und physiologische Untersuchungen zu Belastungsreaktionen bei Lehrern [Psychological and physiological investigation of stress reaction of teachers]. Unpublished Diploma thesis, Universitaet Leipzig.
Blood pressure and psychology 
Ullrich de Muynck, R. U., \& Ullrich, R. (1977). Das Emotionalitaetsinventar als Befindlichkeitsmass: Testmanual EMI-B [The emotionality inventory]. Munchen: Pfeiffer.

WHO-ISH. (1999). World Health Organization - International Society of Hypertension: Guidelines for the management of hypertension. Journal of Hypertension, 17, 151-183.

Wittmann, F. (1989). Psychische und koerperliche Beschwerden im Vergleich zwischen Hypotonikern

Marcus Stueck, Thomas Rigotti, Juliet Roudini, Edgar Galindo, Dian S. Utami und Normotonikern [Mental and physical complaints in the comparison of hypertension and hypotension]. Unpublished Dissertation, Westfaelische Wilhelms-Universitaet Muenster. 